\title{
A Study of Respiratory Symptoms and Disorders among Rice Mill Workers
}

\author{
Roopa Reddy Mulamalla ${ }^{1}$, Abdul Rafi Shaik ${ }^{2}$, Sahithi Reddy Challa ${ }^{3}$ \\ 1Department of Pulmonary Medicine and Critical Care, Vasavi Medical \& Research Centre, Hyderabad, Telangana, \\ India. ${ }^{2}$ Department of Pulmonary Medicine, Shadan Institute of Medical Sciences \& Research Centre, Hyderabad, \\ Telangana, India. ${ }^{3}$ Department of Pulmonary Medicine, Maven Medical Centre, Hyderabad, Telangana, India.
}

\section{ABSTRACT}

\section{BACKGROUND}

In India, rice is the staple food for most people and many people are employed in rice mills. With lack of specific guidelines for rice mills' establishment and operation, workers face a lot of problems especially from respiratory illness. We wanted to determine the pattern of respiratory symptoms and pulmonary function disorders among rice mill workers and provide health education to reduce respiratory morbidity.

\section{METHODS}

A cross-sectional study was conducted during the period October 2016-2018. A total of 50 rice mill workers and 50 normal individuals were assigned to the exposure and control groups respectively. Each individual was interviewed using the British Medical Research Council questionnaire and was later subjected to physical examination, routine laboratory investigations, and pulmonary function tests (PFT). Data was statistically analysed and presented.

\section{RESULTS}

There was a higher prevalence of respiratory symptoms among the rice mill workers when compared to their control counterparts. Cough (28\%) was the predominant symptom and was high in those involved in sweeping and cleaning activities (80 \%). There was a statistically significant difference $(p<0.05)$ among all the spirometric parameters tested like FEV1, FVC, FEV1 / FVC and PEFR except for FEF. About $74 \%$ had respiratory morbidity and obstructive lung diseases (36\%) were predominant as compared to restrictive lung diseases (26\%) and mixed lung disorders (12\%) in the exposure group. Obstructive pattern was predominantly seen in those with a working history of $<10$ years and restrictive and mixed patterns were predominantly seen in those with a working history of $>10$ years. With increase in duration of work, prevalence of respiratory symptoms as well as the severity increased.

\section{CONCLUSIONS}

It can be concluded that rice mill workers are at a higher risk of acquiring respiratory symptoms and lung impairments. Therefore, it is necessary to implement preventive measures by means of controlling dust emission, educating the workers, etc. Workers should also have periodical clinical and spirometric evaluation and those showing significant impairment should be readjusted in other sections of the industry.

\section{KEY WORDS}

Rice Mill Workers, Respiratory Morbidity, Spirometry, Pulmonary Function Tests, Health Education

\author{
Corresponding Author: \\ Dr. Abdul Rafi Shaik, \\ MD, MS Clinf (USA) \\ 612 Mahara Block, Garden Towers, \\ Masab Tank, Hyderabad-500028, \\ Telangana, India. \\ E-mail: rafpulm@gmail.com
}

DOI: $10.14260 /$ jemds/2020/629

How to Cite This Article:

Mulamalla RR, Shaik AR, Challa SR, et al. A study of respiratory symptoms and disorders among rice mill workers. J Evolution Med Dent Sci 2020;9(39):28742879, DOI: 10.14260/jemds/2020/629

Submission 13-06-2019,

Peer Review 18-08-2020,

Acceptance 24-08-2020,

Published 28-09-2020.

Copyright (C) 2020 Roopa Reddy Mulamalla et al. This is an open access article distributed under Creative Commons Attribution License [Attribution 4.0 International (CC BY 4.0)] 


\section{BACKGROUND}

Agriculture related respiratory disorders are one of the first recognized occupational hazards. As early as 1555, Olaus Magnus warned about the dangers of rice grain dust. ${ }^{1}$ The first recorded mention of breathlessness among the handlers of grain was by Ramazzini, the father of Occupational Medicine, in 1713 in his work De Morbis Artificum Diatriba (Diseases of Workers). ${ }^{2}$ According to Buchan and Kramer, ${ }^{3}$ Ramazzini found that nearly all the workers engaged in shifting and measuring grain developed shortness of breath and rarely reached old age. Despite this early recognition, it has only been in the $20^{\text {th }}$ century that this problem has been carefully studied and documented.

India, being a land of agriculture, has formed scaffolding for many agro-based industries. ${ }^{4}$ India is the second biggest rice producing country, and the rice-mill industry is the oldest and largest agro-based industry. ${ }^{4}$ Milling is the process wherein the rice grain is transformed into a form suitable for human consumption. ${ }^{5} \mathrm{~A}$ large quantity of dust is generated into the environment of grain processing industries when agricultural commodities are converted into an edible form for human consumption, thus causing a potential health risk to workers due to inhalation of vegetable dusts.

The work is considered a basic part of our life $^{6}$. The place of work is an important part of man's environment. The health and efficiency of workers in any organization get influenced in large measures by conditions prevailing in their work environment. Most adults spend approximately one-third to one-fourth of their time at work and often perceive work as a part of their self-identity. ${ }^{7}$ It is therefore, essential that this environment should be wholesome and free from any kind of harmful agents as far as possible. Occupational health is a branch of medical science, which deals with the health in its relation to work and working environment. It aims at the adaptation of "work to man" and "man to work". ${ }^{7}$ So far, a wide variety of occupational lung diseases are recognized by law and their number is growing.

With the formidable upsurge in pulmonary physiologic research over the past four decades, a marked increase in our understanding of the functional disturbances \& pathophysiology of lung diseases is seen. ${ }^{8}$ Since the middle of 20th century, medical departments of a large number of factories became concerned, as a number of pulmonary impairment cases with workplace-relationship had developed. Significance of pulmonary functions in assessing respiratory responses to various air borne pollutants has been known and large number of studies have been undertaken to see the effect of dust in various occupations.9,10 Spirometric measurements FVC \& FEV1 are considered as an integral part of epidemiological respiratory health studies.11,12 Only few studies have been conducted all over India (especially in the Telugu states) in relation to effect of rice dust on pulmonary function parameters over the years.

\section{Objectives}

- to determine the pattern of respiratory symptoms and disorders among the rice mill workers.

- to compare the lung function tests of rice mill workers with the control group.
- to determine the factors associated with respiratory morbidity and reduction in pulmonary function among the cases.

- to provide the health education regarding preventive measures to reduce respiratory morbidity among the study population.

\section{METHODS}

The study was approved by the institutional ethical committee of MNR Medical College and Hospital, Sangareddy. This is cross-sectional study conducted over a period of 2 years from October 2016 to October 2018. A total of 50 rice mill workers (selected from 4 rice mills in Hyderabad) and 50 individuals (selected from the general population from the same area matched for age, sex, height, weight and ethnicity on a frequency basis with the study subjects) were assigned to the exposure and the control groups respectively.

\section{Inclusion Criteria}

1. Age greater than 18 years.

2. Who had given the written informed consent.

\section{Exclusion Criteria}

1. Persons having asthma or chronic infections of lungs (before joining the rice mill i.e. pre-placement) or treated recently for any respiratory illness.

2. Workers who had pre-existing known heart diseases, chronic abdominal distress, any gastro-intestinal, and thoracic surgery.

3. Age greater than 60 years.

\section{Sampling Method \\ Purposive Sampling.}

\section{Method of Data Collection}

This study is a Field questionnaire based symptom analysis, PFT based functional disorder analysis. Before data collection, permission and co-operation were sought from owners of each rice mill and the subjects involved in the study. The nature and the purpose of study with associated risks and benefits were also described in detail individually to the entire population, confidentiality of their information was assured, and after that written consent was obtained from all of them.

Each individual was interviewed using the British Medical Research Council (BMRC) questionnaire on Respiratory symptoms $^{13}$ to obtain the basic socio-demographic information, personal data and information on respiratory symptoms. The BMRC questionnaire was translated to Telugu and Hindi by two experts in the field and back translation was done to ensure the uniformity of the questionnaire with its English version.

After taking a detailed history and anthropometric data, physical examination of all the subjects was done with the help of stethoscope and sphygmomanometer. Privacy was maintained during physical examination of female subjects. 
Basic investigations like chest $\mathrm{x}$-ray and blood picture were done whenever required. Before the process of spirometry and after the demonstration of the test, all participants were explained about the steps, manoeuvres, and procedures in detail and were encouraged to practice the manoeuvre before performing the spirometry (as per special reference to the statement of American Thoracic Society).14-16 Pulmonary function tests were performed with an electronic spirometer and the reference values were taken from the European Respiratory Society, Quanjer, 1993 values. ${ }^{17}$ All the pulmonary function tests were carried out at a fixed time of the day between 9 am to $3 \mathrm{pm}$ to minimize diurnal variation. The apparatus was calibrated and operated with an ambient temperature range. The precise technique was based on the operation manual of instruments with special reference to statement of ATS on standardization of spirometry. 14-16 The tests were performed in sitting position with a nose clip to prevent any air leakage. Each test was repeated thrice after adequate rest and the best of the three obtained were recorded. The spirometric measurements observed in this study were FVC, FEV1, FEV1 / FVC \%, FEF 25-75 \% and PEFR.

Grading of severity was done keeping in mind the predominant pattern based on 1986 ATS guidelines. ${ }^{15}$ Individuals with abnormal test results were given primary advice and were encouraged for further follow-up. All the individuals in the exposure group were given health education regarding the personal protective equipment, etc.

\section{Statistical Analysis}

All the collected data were compiled and entered into Microsoft Excel 2016. Data was checked for consistency and completeness, and then analysed using SPSS version 25.0 software. Descriptive statistics were followed, and mean, standard deviation (S.D.), etc. were calculated. Unpaired t test, Chi-square test and One-way ANOVA were used wherever required.

\section{RESULTS}

This observed difference in the prevalence of respiratory morbidity among exposure group and control group was statistically significant (chi-square test value $=11.11 ; \mathrm{p}<0.05$ ). It was observed that as the duration of exposure increases, the prevalence of the respiratory symptoms also increases. Most of the symptoms were highest in those working for a duration of more than 20 years. Cough is the most predominant symptom. The prevalence of respiratory symptoms was high among the employees who were involved in sweeping and cleaning ( $80 \%$ ) the rice mills. The parameters FVC, FEV1 and PEFR showed a significant decline with increase in duration of exposure; whereas the decline in FEV1 / FVC and FEF 25-75 is not statistically significant. Obstructive pattern is the most predominant pattern found in the workers and is predominantly seen in those with a working history of $<10$ years; restrictive pattern and mixed pattern are predominantly seen in those working for a duration of $>10$ years. With increase in duration of employment, there is a progressive deterioration in the lung function test parameters and also an increase in the severity.

\begin{tabular}{|ccc|}
\hline Parameter & Rice Mill Workers & Control Group \\
Age (years) & $39.74+10.66$ & $37.98+11.29$ \\
Male & 36 & 34 \\
Female & 14 & 16 \\
Height $(\mathrm{cm})$ & $167.56+9.01$ & $166.12+8.94$ \\
Weight $(\mathrm{Kg})$ & $67.98+10.04$ & $67.84+11.40$ \\
BMI $\left(\mathrm{Kg} / \mathrm{m}^{2}\right)$ & $24.11+2.10$ & $24.48+2.92$ \\
Smokers & 26 & 28 \\
Non-smokers & 24 & 22 \\
Respiratory Morbidity & 26 & 10 \\
• $\quad$ Present & 24 & 40 \\
- Absent & Table 1. General Information \\
\hline \multicolumn{3}{c}{} \\
\hline
\end{tabular}

\begin{tabular}{|cccccc|}
\hline Duration & Cough & Phlegm & $\begin{array}{c}\text { Chest } \\
\text { Tightness }\end{array}$ & SOB & Wheeze \\
$<\mathbf{5}$ & $1(7.14 \%)$ & $0(0 \%)$ & $1(16.67 \%)$ & $1(11.11 \%)$ & $0(0 \%)$ \\
$5-10$ & $2(14.3 \%)$ & $2(18.2 \%)$ & $1(16.67 \%)$ & $1(11.11 \%)$ & $2(28.6 \%)$ \\
$10-20$ & $4(28.6 \%)$ & $1(9.1 \%)$ & $2(33.3 \%)$ & $3(33.33 \%)$ & $3(42.9 \%)$ \\
$>20$ & $7(50 \%)$ & $8(72.7 \%)$ & $2(33.3 \%)$ & $4(44.44 \%)$ & $2(28.6 \%)$ \\
Total & 14 & 11 & 6 & 9 & 7 \\
\hline \multicolumn{7}{|c|}{ Table 2. Respiratory Symptoms in Relation to Duration of } \\
Employment in Rice Mills in the Exposure Group
\end{tabular}

\begin{tabular}{|cccc|}
\hline Site & Present & Absent & Total \\
Manager / supervisor & $2(25 \%)$ & $6(75 \%)$ & 8 \\
Clerks & $1(20 \%)$ & $4(80 \%)$ & 5 \\
Machine operator & $2(50 \%)$ & $2(50 \%)$ & 4 \\
Loading and unloading & $5(55.56 \%)$ & $4(44.44 \%)$ & 9 \\
Pouring the grains into the machine and & $6(66.67 \%)$ & $3(33.33 \%)$ & 9 \\
filling of bags & $2(40 \%)$ & $3(60 \%)$ & 5 \\
Packaging and branding & $8(80 \%)$ & $2(20 \%)$ & 10 \\
Sweeping and cleaning & $\mathbf{2 6}$ & $\mathbf{2 4}$ & $\mathbf{5 0}$ \\
Total & Table 3. Respiratory Symptoms in Relation to & \\
Site of Working in Rice Mill Workers & \\
\hline
\end{tabular}

\begin{tabular}{|c|c|c|c|c|c|}
\hline Parameter & $\begin{array}{l}\text { Rice Mill } \\
\text { Workers }\end{array}$ & $\begin{array}{l}\text { Control } \\
\text { Group }\end{array}$ & T Value & p Value & $\begin{array}{c}\text { Statistical } \\
\text { Significance }\end{array}$ \\
\hline FEV1 & $2.185+0.76$ & $2.694+0.75$ & 3.38 & $<0.05$ & $\begin{array}{c}\text { Statistically } \\
\text { significant }\end{array}$ \\
\hline FVC & $3.054+0.87$ & $3.395+0.71$ & 2.16 & $<0.05$ & $\begin{array}{c}\text { Statistically } \\
\text { significant }\end{array}$ \\
\hline FEV1 / FVC & $\begin{array}{c}72.054+ \\
14.09\end{array}$ & $\begin{array}{c}78.758+ \\
10.67\end{array}$ & 2.68 & $<0.05$ & $\begin{array}{c}\text { Statistically } \\
\text { significant }\end{array}$ \\
\hline FEF 25-75 \% & $2.74+0.66$ & $2.77+0.77$ & 0.19 & $>0.05$ & $\begin{array}{c}\text { Not statistically } \\
\text { significant }\end{array}$ \\
\hline PEFR (L / min) & $\begin{array}{c}334.497+ \\
119.5\end{array}$ & $\begin{array}{c}410.02+ \\
121.63\end{array}$ & 3.13 & $<0.05$ & $\begin{array}{c}\text { statistically } \\
\text { significant }\end{array}$ \\
\hline
\end{tabular}

between the Exposure and Control Groups

\begin{tabular}{|cccccc|}
\hline Duration & Normal & Obstructive & Restrictive & Mixed & Total \\
$<5$ YEARS & $10(66.67 \%)$ & $4(26.67 \%)$ & $0(0 \%)$ & $1(6.67 \%)$ & 15 \\
$5-10$ & $2(15.4 \%)$ & $8(61.5 \%)$ & $2(15.4 \%)$ & $1(7.7 \%)$ & 13 \\
$10-20$ & $1(1.11 \%)$ & $4(44.44 \%)$ & $4(44.44 \%)$ & 0 & 9 \\
$>20$ & $0(0 \%)$ & $2(15.4 \%)$ & $7(53.8 \%)$ & $4(30.8 \%)$ & 13 \\
Total & $13(26 \%)$ & $18(36 \%)$ & $13(26 \%)$ & $6(12 \%)$ & 50 \\
\hline Table 5. Spirometric Patterns in Relation to Duration of Employment \\
\hline
\end{tabular}

\section{DISCUSSION}

Rice dust contains particles which may contain large number of contaminants including silica, fungi and other metabolites, bacterial endotoxins, insects, mites, debris, chemical additives such as pesticides and herbicides. ${ }^{18}$ During the mill operations, lots of dust was seen to pollute rice mill atmosphere due to milling, filling the bags, loading and unloading, etc. Grain dust has a long history of association with disease, and its adverse effects on various organs such as eyes, nose, skin, lung and the airways have been described. ${ }^{19}$ General health may be seriously compromised by dust, and it can easily escape our casual attention. ${ }^{5}$ Respiratory symptoms are main health complaints in every grain dust related occupation. In the 
present study, the exposure group presented with cough as the most prevalent symptom. Cough is the predictor and precursor symptom of all respiratory problems and is a respiratory reflexive physiology. ${ }^{20}$ The higher prevalence of respiratory symptoms in the study group may be due to the irritant effects of rice husk dust exposure together with allergic responses either due to protein constituent of rice husk or microbiological containment as reported by Lim et al $^{21}$ and Dhillon et al.22

In this study, it was observed that as the duration of exposure increases, the prevalence of the respiratory morbidity also increases. The prevalence of respiratory morbidity was high among the employees who were involved in sweeping and cleaning the rice mill and this is probably because they are at a higher risk of exposure to dust than those involved in other sectors. Less usage of personal protective equipment and poor ventilation may also have contributed to the higher prevalence of respiratory symptoms in this group.

As reported by Boyd et al,23 many industrial processes produce air-borne contaminants and their most common route of absorption is by inhalation. Industrial dust inhalation over a long period leads to proliferative and fibrotic changes in the lungs. ${ }^{23}$ Pulmonary function tests have been beneficial in the early recognition of pulmonary dysfunctions in patients considered to be normal on the basis of clinical and radiological examination. ${ }^{22}$

The decline in FVC found in the current study was parallel with the studies done by S K Singh et al ${ }^{24}$, Chandrathilaka et $\mathrm{al}^{25}$ Dhillon et $\mathrm{al}^{22}$ and Wickramage et $\mathrm{al}^{26}$ which is suggestive of changes in bronchi and elastic component of lungs. ${ }^{27}$

The FEV1 values between the exposure and the control group in the current study are consistent with the studies done by Chandrathilaka et $\mathrm{al}^{, 25}$ Dhillon et $\mathrm{al}^{22}$ Uma et $\mathrm{al}^{27}$ and Wickramage et al. ${ }^{26}$ Decrease in FEV1 shows that exposure to dust causes early obstructive pulmonary impairment which further increases with increase in number of years of exposure. ${ }^{28}$ This may be due to release of air borne endotoxin which may cause inflammatory reaction in the bronchopulmonary system. ${ }^{29}$

The Forced Expiratory Flow between 25 and $75 \%$ of the FVC (FEF 25-75 \%) is one of the most commonly cited measures of small airways pathology ${ }^{30}$. Therefore, owing to the almost similar degrees of tobacco smoke induced small airway damage in rice millers and controls, both groups seem to have similar mean FEF25-75 \% values. ${ }^{31}$ The harmful effects of tobacco smoke overriding grain dusts have been noted when Cotton et $\mathrm{al}^{32}$ observed the harmful effects of tobacco smoke to be more pronounced than that of grain dusts.

The decrease in PEFR is probably due to hypertrophy of mucosal cells due to irritation by grain dust and smoke resulting in the increased secretion of mucus and formation of mucosal plugs which cause obstruction to the exhaled air. ${ }^{33}$

When air pollutants are breathed into the lungs, the harmful particles which bypass the lung defense mechanisms such as hairs in nostrils, mucus membrane lining the nasal passage and pharynx and ciliary action, may get trapped in the alveoli, causing a localized inflammatory response. ${ }^{34}$ Enzymes such as elastase are released during this inflammatory response, causing alveolar septal disintegration. ${ }^{34}$ The inflammatory response also causes impairment of lung defense mechanisms and disruption of lung tissue repair mechanisms. ${ }^{34}$ This may lead to significant deformities in lung architecture, including loss of lung elastic recoil, leading to functional consequences. ${ }^{34}$ A similar chronic inflammatory response in the lungs can be expected due to long term exposure to rice husk dust. This may play a role in chronic reductions in lung functions in those exposed to rice husk dust.

The present study confirms the findings of others and suggests that rice husk dust adversely affects lung function parameters, such as FVC, FEV1 and PEFR suggesting an obstructive pattern of lung function impairment which is associated with the dose - effect of years of exposure to husk dust. Increase in duration of working at rice mill increases the lung damage causing both airway obstruction and interstitial involvement. ${ }^{35}$

\section{Recommendations}

The following recommendations can be used to avoid the rice dust exposure among the rice mills $25,26,35-39$

- Use of protective devices such as respiratory masks and goggles by these workers in order to reduce the occupational exposure to dust.

- Dust reduction measures in the mill environment by proper ventilating systems.

- Cleaning the floor of the rice mill only after wetting it.

- Provision of occupational health services to the workers, which include pre-placement examination and routine health check-ups (at least every quarterly)

- Providing health education and rationalization of the work methods so as to improve the health and safety of the workers.

- All the employees with cough for more than 2 weeks should be counselled to go for sputum testing.

- Encouraging the workers to reduce or to stop smoking so as to prevent the development of harmful effects of smoking to themselves and to others.

- Legal framework is needed to ensure protection of workers' health. (1996 YANT Award Lecture on occupational hygiene).

\section{Limitations}

- The sample size taken here is less and the study area is restricted because of resource constrain. Hence, the drawn results can't be extrapolated with the total population.

- Etiological diagnosis of respiratory morbidity is not possible by pulmonary function tests.

- The manoeuvre during spirometry is highly dependent on co-operation and effort of the individuals. So, there may be underestimation of FVC.

\section{CONCLUSIONS}

Considering all the factors, it can be concluded that rice mill workers are at a high risk of acquiring respiratory symptoms and lung impairments. There is an urgent need to address rice mill employers and employees about the dangers of rice dust exposure, and also educate them about the various preventive measures to be taken. Workers should also have periodical clinical and spirometric evaluation and those showing 
significant impairment in ventilatory functions should be readjusted in other sections of the industry where exposure to industrial dust is negligible. Further epidemiological and pathological studies involving large number of rice mill workers should be carried out which will lead to better understanding of the problems and improvement in work design.

Financial or Other Competing Interests: None.

\section{REFERENCES}

[1] Magnus 0. Historia de gentibus septentrionalibus. Romae (Facsimile Copenhagen 1970). Engl transl 1996;1998:1555.

[2] Ramazzini B. De Mortis Artificum Diatriba. The Latin text of 1713 , rev. with translation and notes by W. C. Wright. Chicago, IL (USA): University of Chicago Press 1940.

[3] Buchan R, Kramer G. A field test of a procedure for the identification of protein-bearing particles in grain elevator air. ACS Publications 1980:301-7.

[4] Nayak P. Problems and prospects of rice mill modernization: a case study. J Assam University 1996;1(1):22-8.

[5] Batsungnoen K, Kulworawanichpong T. Effect of dust particles in local rice mills on human respiratory system. World Academy of Science, Engineering and Technology 2011;80:421-6.

[6] Mahmoud TM, Abd El-Megeed HS, Alaa El Din SM, et al. A study of occupational health hazards among assiut spinning factory workers. Ass Univ Bull Environ Res 2004;7(1):63-74.

[7] Randorph SA. Roles of occupational health nurse. In: Rogers B, ed. Occupational health nursing. Philadelphia, PA: W.B. Saunders Company 1994:48-64.

[8] Reuben M, Cherniack. Disease a month: evaluation of Resp. junction in health and disease. Mosby Publication 1992.

[9] Hankinson JL, Reger RB, Morgan WKC. Maximal expiratory flows in coal miners. American Review of Respiratory Disease 1977;116(2):175-80.

[10] Townsend MC, Enterline PE, Sussman NB, et al. Pulmonary function in relation to total dust exposure at a bauxite refinery and alumina-based chemical products plant. American Review of Respiratory Disease 1985;132(6):1174-80.

[11] Raffle PA, Adams PH, Baxter PJ, et al, eds. Hunter diseases of occupations-the occupational history. London: Edward Arnold Publication 1994:3-15.

[12] Seaton A. A short history of lung disease. In: Morgan WKC, Seaton A, eds. Occupational lung diseases. $3^{\text {rd }}$ edn. London: W.B. Saunders Co 1995:1-8.

[13] Cotes JE. Medical research council questionnaire on respiratory symptoms (1986). Lancet 1987;2(8566):1028.

[14] Renzetti AD. Standardization of spirometry. Am Rev Respir Dis 1979;119(5):693-4.

[15] Standardization of spirometry--1987 update. Statement of the American Thoracic Society. Am Rev Respir Dis 1987;136(5):1285-98.
[16] Standardization of Spirometry, 1994 Update. American Thoracic Society. Am J Respir Crit Care Med 1995;152(3):1107-36.

[17] Quanjer PH, Tammeling GJ, Cotes JE, et al. Lung volumes and forced ventilatory flows. Report Working Party Standardization of Lung Function Tests, European Community for Steel and Coal. Official Statement of the European Respiratory Society. Eur Respir J Suppl 1993;16:5-40.

[18] Bates DV. Air pollutants and the human lung. The James Waring Memorial lecture. Am Rev Respir Dis 1972;105(1):1-3.

[19] Hurst TS, Dosman JA. Characterization of health effects of grain dust exposures. Am J Ind Med 1990;17(1):27-32.

[20] Ansari MMH, Karim MR, Mashud I. Symptoms of respiratory health problems in rice mill workers of Bangladesh. KYAMC Journal 2017;7(2):758-61.

[21] Lim HH, Domala Z, Joginder S, et al. Rice millers' syndrome: a preliminary report. $\mathrm{Br} \mathrm{J}$ Ind Med 1984;41(4):445-9.

[22] Dhillon SK, Bassi R, Kaur H. A study of lung function abnormalities in workers of rice Mills. Indian J Fundamental Applied Life Sci 2011;1(3):217-20.

[23] Boyd W. Text book of pathology. London: Henley K 1977: p. 721.

[24] Singh SK, Nishith SD, Tandon GS, et al. Some observations of pulmonary function tests in rice mill workers. Indian J Physiol Pharmacol 1988;32(2):152-7.

[25] Chandrathilaka KR, De Awis SS, Lankatilake KN, et al. Work environment of automated and non-automated rice mills in Amapara district, Sri Lanka. Int J Community Med Public Health 2018;5(8):3257-64.

[26] Wickramage SP, Rajaratne AAJ, Udupihille M. Are rice millers an at-risk group for lung disease?-an occupational health concern in rural Sri Lanka. Indian J Physiol Pharmacol 2017;61(4):340-7.

[27] Uma R, Rajeshwari L. Susceptibility towards obstructive lung change (FEV1/FVC) in rice mill workers in comparison to normal adult individuals. Int J Biol Med Res 2016;7(2):5534-6.

[28] Rao NM, Saiyed HN, Kashyap SK, et al. Airway obstruction in silicosis workers. Lung India 1991;9(4):126-9.

[29] Bose S, Roohi F, Agarwal B. Lung function tests and immunoglobulin E in Dal mill workers. Indian Journal of Physiology and Allied Sciences 1997;51(3):101-8.

[30] McNulty W, Usmani OS. Techniques of assessing small airways dysfunction. Eur Clin Respir J 2014;1(1):25898.

[31] Bhargava EK, Khaliq F. Short communication effect of paternal smoking on the pulmonary functions of adolescent males. Indian J Physiol Pharmacol 2008;52(4):413-9.

[32] Cotton DJ, Graham BL, Li KY, et al. Effects of grain dust exposure and smoking on respiratory symptoms and lung function. J Occup Med 1983;25(2):131-41.

[33] Taytard A, Tessier JF, Vergeret J. Respiratory function in flour mill workers. European Journal of Epidemiology 1988;4:104-9.

[34] MacNee W. Pathology, pathogenesis, and pathophysiology. BMJ 2006;332(7551):1202-4.

[35] Itagi V, Patel MB, Patil RS. Analysis of lung functions in flour mills and ricemills workers. Indian Journal of Applied Basic Medical Sciences 2010;12(15). 
[36] Rana MC, Naskar S, Roy R, et al. Respiratory morbidity among rice mill workers in an urban area of Burdwan District, West Bengal: a cross-sectional study. Indian J Occup Environ Med 2018;22(1):5-10.

[37] Ghosh T, Gangopadhyay S, Das B. Prevalence of respiratory symptoms and disorders among rice mill workers in India. Environ Health Prev Med 2014;19(3):226-33.
[38] Ratnaprabha GK, Manjunath. Respiratory morbidities and pulmonary function tests of rice mill workers in a city of Karnataka. J Pub Health Med Res 2016;4(1):1-5.

[39] Naik PR, Nirgude AS, Megana P. Respiratory morbidity and peak expiratory flow rate among rice mill workers in a rural area of south India. Natl J Community Med 2017;8(5):246-9. 